\title{
Evaluation of surface roughness after milling with a tool with modified vibration damper
}

\author{
Ocena chropowatości powierzchni po frezowaniu \\ narzędziem ze zmodyfikowanym tłumikiem drgań
}

\section{PIOTR LÖSCHNER \\ PIOTR NIESŁONY \\ ROMAN CHUDY \\ PAWEK BIKOUS \\ MAREK LIPOWCZYK *}

This article presents the research results regarding chosen surface roughness parameters after milling with a standard holder and a holder equipped with a special modified vibration damper. The experimental research was conducted on a novel research stand. Obtained results have confirmed a positive effect of the modified vibration damper on machined surface quality.

KEYWORDS: milling, vibration damping holder, surface roughness

The vibrations present in the cutting process are one of the usual technological problems. They greatly affect the surface quality and efficiency of the cutting process [1-3], as well as the durability of the tool and the machine tool $[4,5]$. The main source of vibration during machining is the timevarying cutting force which results from the technological and geometrical conditions of the cutting tool's cutting edge of the material.

There are many methods to reduce vibrations in the cutting process. One of the most frequently used is the appropriate selection of technological parameters of processing [7]. It is also possible to limit vibrations by changing the dynamic characteristics of the cutting tool or interfering with the fastening system of the workpiece. In this article, the authors focused on the assessment of surface quality after milling with two types of tools, differing in the damping characteristics of the tool holders used.

\section{Research position, scope and methodology of research}

The modern, four-axis MA600HB milling center from OKUMA was selected for experimental research. It is characterized by a very rigid construction and high spindle power $(22 \mathrm{~kW})$. The machine has been equipped with a specially designed device fixing research samples. The construction shown in fig. 1 allowed reproducible experimental tests to be carried out under set processing conditions.

\footnotetext{
* Mgr inż. Piotr Löschner (pleszner1@gmail.com), dr hab. inż. Piotr Niesłony, prof. PO (p.nieslony@po.opole.pl), mgr inż. Roman Chudy (romanchudy87@gmail.com) - Katedra Technologii Maszyn i Automatyzacji Produkcji, Wydział Mechaniczny Politechniki Opolskiej; Paweł Biłous, Marek Lipowczyk (pawel@ferrpol.pl) - Ferrpol Bracia Matuszewscy Sp. z o.o.
}

Thanks to the appropriate clamping system, the sample machining was characterized by variable rigidity, evaluated depending on the tool path. The workpiece is made of 50 $\mathrm{mm}$ thick $\mathrm{S} 355 \mathrm{~N}$ sheet, profiled to ensure roughness after machining at any height of the surface to be processed. The testing equipment was equipped with Vischer \& Bolli pins of a special design, thanks to which it was possible to fix it and attach it to the machine table with very high accuracy, without the need to re-homing.

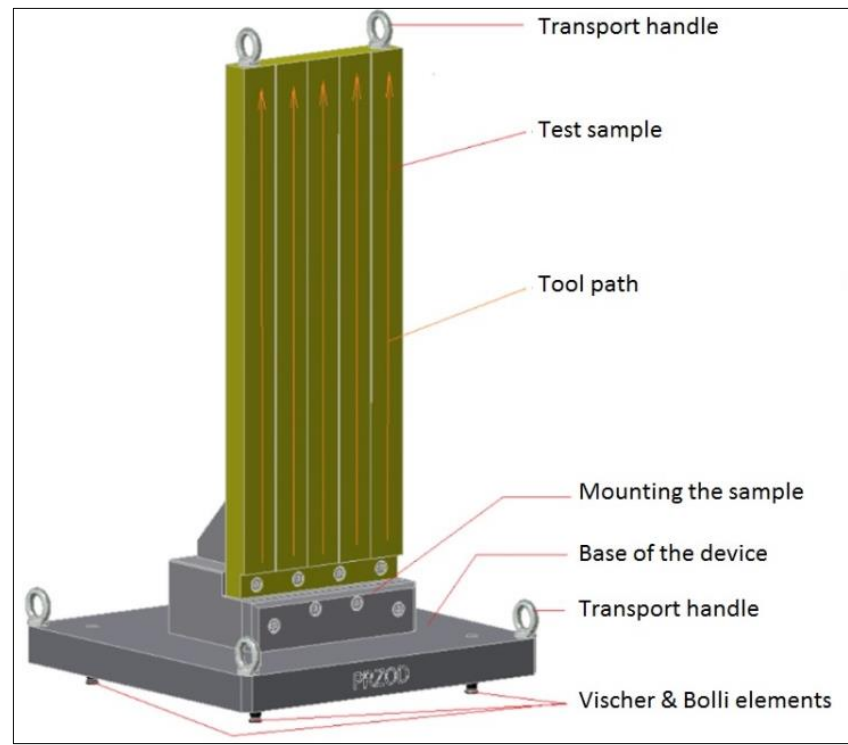

Fig. 1. Test equipment with modular fixing

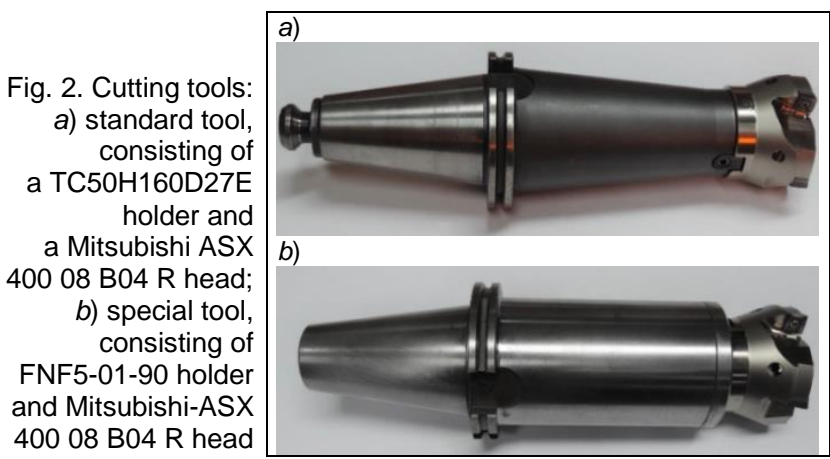


Two types of milling tools were used to conduct experimental research. The first tool consisted of standard commercial modules. The second tool was equipped with a grip with a built-in vibration damper, developed by Ferrpol. A characteristic feature of both tools is the equal length of the overhang of the assembled system and the use of an identical milling head.

The first tool (fig. 2a) was built from a standard holder type TC50H160D27E with SK50 shank and Mitsubishi head with diameter $\varnothing 80$ and ASX marking 40008 B04 R The too head was equipped with four SOMT 12 T 308 PEER-JH plates with VP15TF.

The same head was used in the second tool (fig. 2b), which consisted of a special holder FNF5-01--90 with the SK50 shank, equipped with a vibration damper with specific geometry and with a polyurethane filling.

The tests were carried out on two test plates, made of the same material and in the same processing technology to preserve identical initial conditions. The first set of tests was performed using a standard tool, with the parameters given in the table.

TABLE. Research plan for a standard tool and a tool with a modified vibration damper

\begin{tabular}{|l|c|c|c|c|c|}
\hline Path & 1 & 2 & 3 & 4 & 5 \\
\hline $\begin{array}{l}\text { Cutting speed } \\
v_{c}, \mathrm{~m} / \mathrm{min}\end{array}$ & 250 & 300 & 350 & 400 & 450 \\
\hline $\begin{array}{l}\text { Feed per blade } \\
f_{\mathrm{z}}, \mathrm{mm} / \mathrm{blade}\end{array}$ & \multicolumn{5}{|c|}{0,2} \\
\hline $\begin{array}{l}\text { Cutting depth } \\
a_{\mathrm{p}}, \mathrm{mm}\end{array}$ & \multicolumn{5}{|c|}{1,5} \\
\hline $\begin{array}{l}\text { Cutting width } \\
a_{\mathrm{e}}, \mathrm{mm}\end{array}$ & 48 \\
\hline
\end{tabular}

The second set of tests was repeated, for identical technological conditions on the next board, a tool with a vibration damper. The research plan assumed an evaluation of the tool functionality with a vibration damper only in the aspect of the variable cutting speed $v_{c}$ - from the interval $250 \div 450 \mathrm{~m} / \mathrm{min}$. Other technological parameters were unchanged. The main criterion for the functionality of the tool with the vibration damper was the surface roughness evaluated within 12 fields (from $A$ to $L$ ) with a height of 60 $\mathrm{mm}$ each (fig. 3 ). Within each field, eight repetitions of the roughness profile measurement were made, which were averaged and statistically developed.

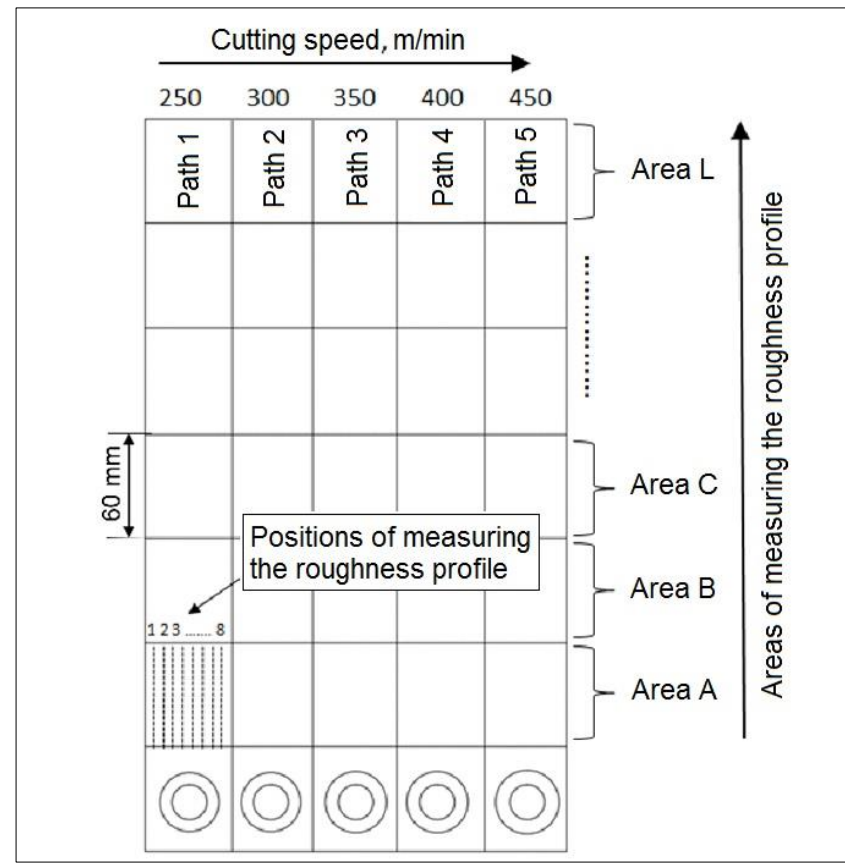

Fig. 3. Scheme for determining the areas and measurement positions of the roughness profile for a fixed range of cutting speeds

\section{Analysis of test results}

The surface roughness was measured using a MAHR MarSurf PS 10 photochester. A number of parameters were evaluated, three of which were selected: $R a, R z$ and $R p$. Fig. 4 and fig. 5 present the roughness results for representative cutting speed values.

Analyzing these results, it can be stated that up to the height of milling corresponding to field $E$ (fig. 4), i.e. approx. $300 \mathrm{~mm}$ from the place of attachment, in the speed range $v_{c}$ $=250 \div 350 \mathrm{~m} / \mathrm{min}$, lower values of $R a$ were obtained in the case of the use of a vibration damper tool. The use of a modified vibration damper reduced the $R a$ parameter by an average of $40 \%$ compared to the commercial tool.

At higher cutting speed $v_{\mathrm{c}}=450 \mathrm{~m} / \mathrm{min}$, the best roughness was obtained after using a commercial tool - in this case the $R a$ value decreased from $0.8 \div 0.9 \mu \mathrm{m}$ to 0.5 $\mu \mathrm{m}$. For this tool, it is therefore rational to use higher cutting speeds.

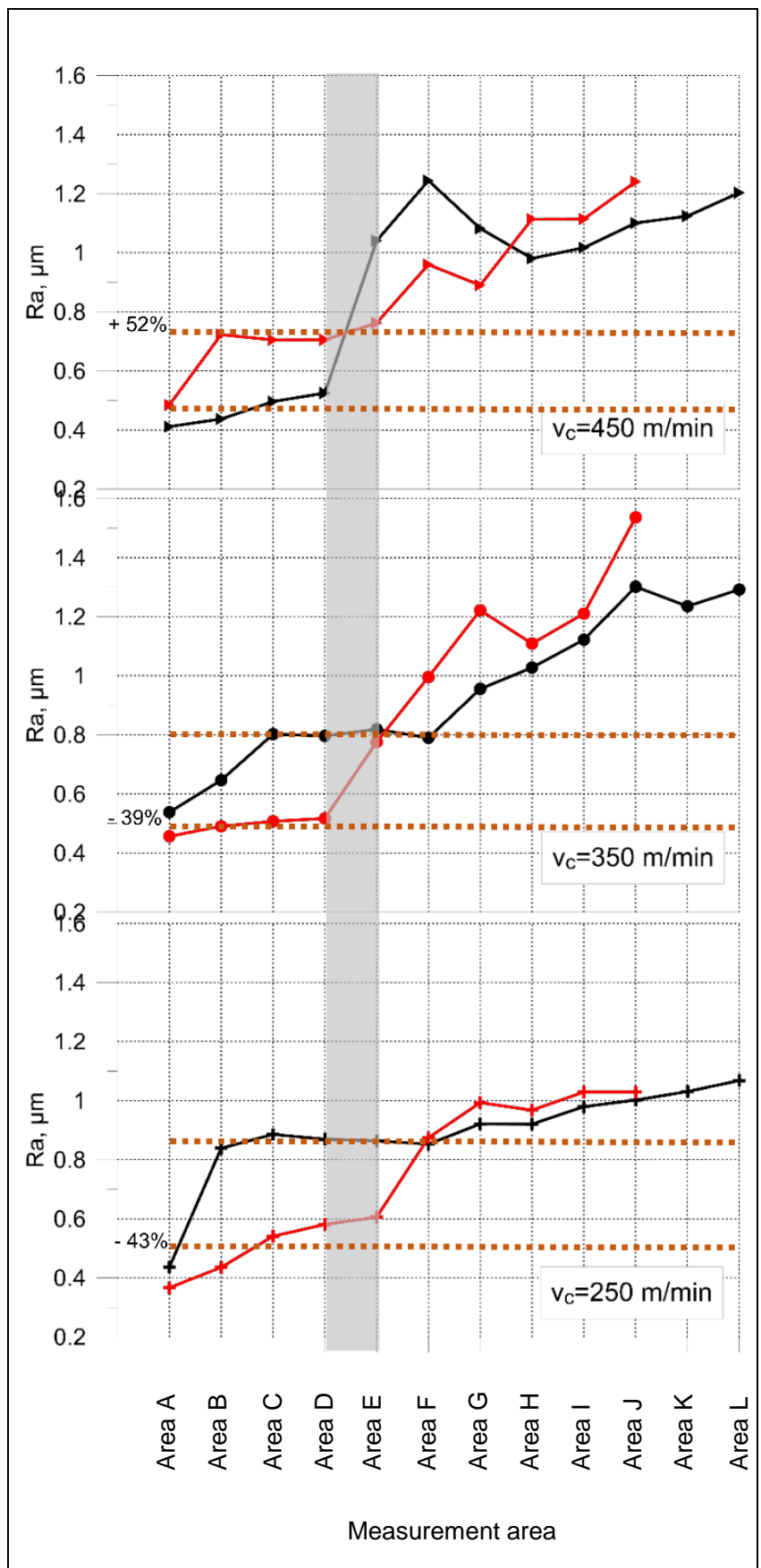

Fig. 4. Mean values of changes in the Ra parameter in the function of the measurement field and cutting speed obtained during milling with a classical tool (black lines) and a tool with a modified vibration damper (red lines) 


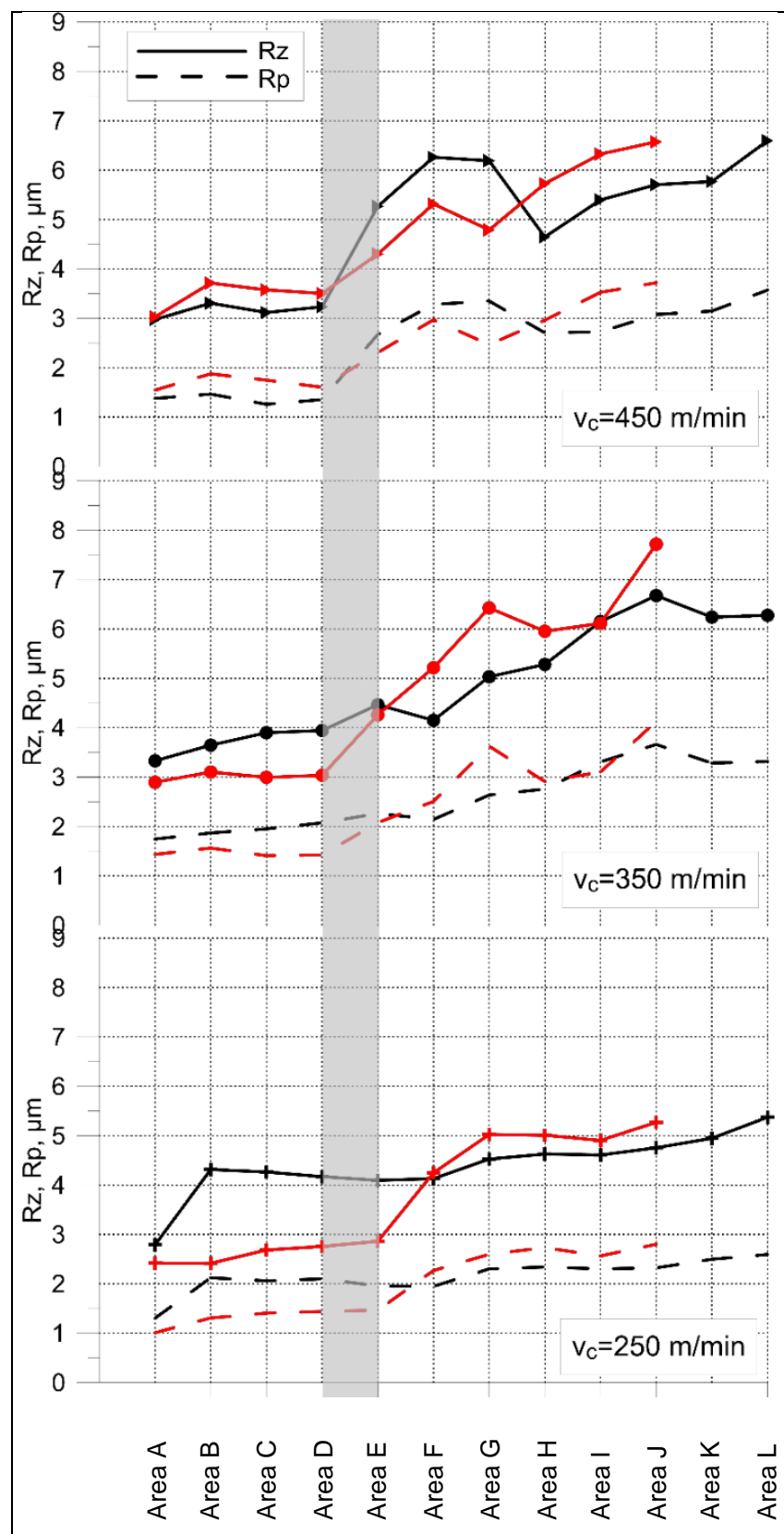

Measurement area

Fig. 5. Mean values of changes in $R z$ and $R p$ parameters in the function of the field of measurement and cutting speed, obtained after milling with a classical tool (black lines) and tool with modified vibration damper (red lines)

At the milling height over $300 \mathrm{~mm}$, that is in the area of the $E \div L$ fields, the characteristic of changes in the $R a$ value in relation to the tested tools is comparable. As $R a$ moves away from the mounting place, $R a$ grows, reaching $1.2 \div 1.5$ $\mu \mathrm{m}$.

The Ra parameter represents the arithmetic means of the profile deviation from the mean line, so it is not sensitive to a series of profile disturbances. An additional assessment of surface quality based on $R z$ and $R p$ (fig. 5) was carried out for this reason. A similar character of the changes in the values of these parameters was observed, although with the increase in $v_{c}$ the differences between $R z$ in favor of the silencer tool are reduced - for $v_{\mathrm{c}}=250 \mathrm{~m} / \mathrm{min}$ the difference is about $40 \%$, while for $v_{\mathrm{c}}=350 \mathrm{~m} / \mathrm{min}$ only $25 \%$.

In addition, regardless of the tools used, stabilization of the roughness parameters ( $R a, R z$ and $R p$ ) for $B \div E$ fields was observed, which corresponds to the more rigid area of the test plate. It was also noted that the roughness profile obtained during these milling tests is very symmetrical. For all analyzed cases, the value of parameter Rp corresponded to approximately half of the value of $R z$. As it is known, $R z=R p+R v(R p$ is the height of the highest elevation, and $R v$ - the depth of the lowest recess of the profile). Thus, a symmetrical profile is obtained, which is not affected in any significant way by the influence of machining vibrations.

\section{Conclusions}

Vibrations are an inseparable element of the cutting process. Designers are looking for different solutions to reduce as much as possible the negative impact of vibrations during machining. The presented solution of the cutting tool, equipped with a special frame with a vibration damper, confirms the possibility of influencing the vibration characteristics of the process through the introduction of appropriate structural changes in the area of cutting tools.

The presented research results and the analysis of roughness parameters make the following conclusions:

- modified tool, equipped with a special frame with vibration damper, it best fulfills its role (due to the possibility of obtaining a minimal roughness) in the case of surface treatment at lower cutting speeds;

- at $v_{\mathrm{c}}=250 \mathrm{~m} / \mathrm{min}$, the use of a modified tool resulted in a reduction in roughness - both $R a$ and $R z$ parameters almost $40 \%$;

- regardless of the tools used, the roughness parameter values stabilized for the stiffer test disc area;

- the roughness profile obtained during milling tests is symmetrical, as indicated by the values of $R z$ and $R p$ parameters.

The use of a modified vibration damper tool is rationally justified. However, it is necessary to precisely specify the scope of technological parameters at which the tool will function properly. It was unequivocally stated that the use of a modified tool did not negatively affect the quality of the surface being processed, and the indicated benefits may support the further development and improvement of this construction.

\section{REFERENCES}

1. Jemielniak K., Nejman M., Śniegulska-Grądzka D. „Analityczne i numeryczne wyznaczanie granicy stabilności przy toczeniu". Inżynieria Maszyn. 17 (2012): pp. 81-92.

2. Szulewski P., Śnieguska-Grądzka D. „Systemy automatycznego monitorowania drgań w obrabiarkach". Mechanik. 3 (2017): pp. 170-175.

3. Vikram K., Ratnam Ch., Sankar K. "Vibration diagnosis and prognostics of turn-milling operations using HSS and carbide end mill cutters". Procedia Technology. 23 (2016): pp. 217-224.

4. Cheng Z., Xia Zhu M. "Kinematics simulation and vibration mode analysis of micro turn-milling machine tool". Key Engineering Materials. 589 (2014): pp. 378-383.

5. Liu K., Zhang Z., Jin X. "Analysis of the vibration mechanism in the turn-milling machining of micro-miniature shafts". Advanced Materials Research. 652 (2013): pp. 2232-2236.

6. Weremczuk, A., Rudzik M., Rusinek R. „Badania doświadczalne stabilności procesu frezowania stopu Inconel X750”. Mechanik. 88 (2015): pp. 61-63.

7. Parus A., Hoffmann M., Bodnar A. „Zastosowanie aktywnych układów eliminacji drgań w procesie skrawania”. Inżynieria Maszyn. 16 (2011): pp. 82-94.

Translation of scientific articles, their computer composition and publishing them on the website www.mechanik.media.pl by original articles in Polish is a task financed from the funds of the Ministry of Science and Higher Education designated for dissemination of science.

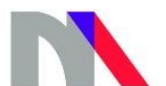

